\title{
Keanekaragaman Jenis Capung Famili Libellulidae di Bukit Cogong Kabupaten Musi Rawas
}

\section{Diversity Species of Dragonflies Family of Libellulidae in Bukit Cogong Musi Rawas District}

\author{
Merti Triyanti $^{*}$, Destien Atmi Arisandy ${ }^{1}$ \\ ${ }^{1}$ Program Studi Pendidikan Biologi, STKIP PGRI Lubuklinggau \\ Jl Mayor Toha, Kel. Air Kuti, Kec. Lubuk Linggau Timur I, Kota Lubuk Linggau, Sumatera Selatan, Indonesia \\ Emai:mertitriyanti28@gmail.com \\ *Penulis Korespondensi
}

\begin{abstract}
There are many species of dragonflies in Cogong Hill, Musi Rawas Regency, but not yet well recorded, so it is necessary to collect data on species of dragonflies and studies on diversity. Therefore, the research was conducted to study the diversity of dragonflies of the Libellulidae family in Cogong Hill, Musi Rawas Regency. This research uses the technique of exploring transects by determining 3 observation stations. Each station consists of 5 transects with a transect area of $100 \times 100 \mathrm{~m}$. The capture of the Libellulidae family in Bukit Cogong, Musi Rawas Regency using a net net, was identified by observing the morphological characteristics of the dragonflies of the libellulidae family. Five species of dragonflies from the Libellulidae family were found, namely: Orthetrum sabina, Neurothemis fluctuans, Bracythemis contaminata, Rhodothemis rufa, and Onycothemis culminicola. The highest species composition is Orthetrum sabina by $46.34 \%$, while the lowest is Onycothemis culminicola by $6.09 \%$. Uniformity index at all stations in high category, stable community, dominance index $(C)$ in low category, and diversity index is low with a value is 1.61 .
\end{abstract}

Keywords: Diversity, Dragonfly, Cogong Hill, Libellulidae

\begin{abstract}
Abstrak
Spesies capung di Bukit Cogong Kabupaten Musi Rawas banyak ditemukan, namun belum terdata dengan baik sehingga perlu dilakukan pendataan jenis capung dan kajian mengenai keanekaragaman. Oleh karena itu, penelitian ini dilakukan untuk mengkaji keanekaragaman capung famili Libellulidae di Bukit Cogong Kabupaten Musi Rawas. Penelitian ini menggunakan teknik menjelajah transek dengan menentukan 3 stasiun pengamatan. Setiap stasiun terdiri dari 5 buah transek dengan luas transek 100x100 m. Penangkapan famili libellulidae di Bukit Cogong Kabupaten Musi Rawas menggunakan jaring net, pengidentifikasian dengan melakukan pengamatan ciri-ciri morfologi capung famili Libellulidae. Terdapat 5 spesies capung dari famili Libellulidae yang ditemukan, yaitu: Orthetrum sabina, Neurothemis fluctuans, Bracythemis contaminata, Rhodothemis rufa, dan Onycothemis culminicola. Komposisi jenis yang paling tinggi yaitu Orthetrum sabina sebesar 46,34\%, sedangkan yang paling rendah yaitu Onycothemis culminicola sebesar 6,09\%. Indeks keseragaman termasuk kategori tinggi, komunitas stabil, indeks dominansi (C) termasuk kategori rendah dan indeks keanekaragaman termasuk kategori rendah dengan nilai sebesar 1,61.
\end{abstract}

Kata Kunci: Keanekaragaman, Capung, Bukit Cogong, Libellulidae

Diterima: 15 Juli 2020, disetujui: 20 Januari 2021

\section{Pendahuluan}

Ekosistem merupakan unit fungsional lingkungan yang dibangun oleh komponen hidup (biotik), dan komponen non hidup (abiotik) pada lingkungan (Rizal et al., 2015). Makhluk hidup dari berbagai jenis yang hidup secara alami di suatu tempat membentuk kumpulan yang di dalamnya setiap individu menemukan lingkungan yang dapat memenuhi 
kebutuhan hidupnya. Kelompok yang hidup secara bersama telah menyesuaikan diri dan menghuni suatu tempat alami yang kemudian disebut komunitas (Mardiyanti et al., 2013). Salah satunya adalah komunitas yang ada di hutan. Hutan merupakan salah satu komponen penting untuk menunjang kehidupan manusia, selain itu pada ekosistem hutan juga terdapat beranekaragam jenis serangga, termasuk capung. Habitat capung dengan penyebaran luas, mulai dari hutan, kebun, sawah, sungai danau, dan lain-lain. Keberadaan capung dapat dijumpai mulai dari tepi pantai sampai pada ketinggian lebih dari $3.000 \mathrm{mdpl}$. Beberapa jenis capung, memiliki kemampuan terbang yang baik dan memiliki daya jelajah wilayah yang luas, namun beberapa jenis lainnya merupakan penerbang yang lemah dan memiliki daya jelajah yang sempit (Ansori, 2008).

Capung dapat juga disebut sebagai bioindikator air bersih karena nimfa capung tidak akan hidup di air yang sudah tercemar atau sungai yang tidak terdapat tumbuhan di dalamnya. Perubahan populasi capung merupakan tanda tahap awal pencemaran air di samping pertanda lain seperti kekeruhan air dan melimpahnya ganggang hijau. Oleh karena itu, pelestarian capung harus disertai dengan melihara tempat hidupnya (Suriana, 2014). Selain itu, capung juga berperan sebagai predator serangga kecil lainnya, bahkan kanibal, sehingga kehadiran capung dalam suatu ekosistem dapat di jadikan indikator keseimbangan ekosistem terbesar terutama hutan (Pamungkas et al., 2015). Salah satu hutan yang menjadi tempat tinggal capung adalah Bukit Cogong.

Bukit Cogong merupakan suatu hutan yang terbentuk secara alami dan dilestarikan oleh manusia. sumber air yang ada di Bukit Cogong berasal dari sumber air permukaan, mata air tanah dan air hujan. Semakin pesatnya perkembangan kota membuat daerah di sekeliling kawasan Bukit cogong telah dialihfungsikan menjadi tempat pemukiman, bahkan di Bukit Cogong tersebut telah dibangun tempat rekreasi buatan seperti tempat bermain anak-anak (Cahyono, 2013). Berdasarkan pengamatan yang telah dilakukan di Bukit Cogong kabupaten Musi Rawas, banyaknya wisatawan yang berkunjung mendorong pemerintah gencar melakukan pembangunan di kawasan objek pariwisata. Adanya pembangunan tersebut dikhawatirkan akan merubah habitat asli dan keanekaragaman hayati di wilayah ini.

Observasi yang dilakukan di Bukit Cogong Kabupaten Musi Rawas, memberikan informasi bahwa banyak ditemukan jenis-jenis capung. Namun demikian, data mengenai jenis-jenis capung tersebut belum tersedia terutama untuk capung famili Libellulidae. Selain itu, indeks keanekaragamannya pun belum diketahui, sehingga perlu dilakukan kajian mengenai ini. Oleh karena itu, penelitian ini dilakukan untuk mengkaji keanekaragaman capung famili Libellulidae di Bukit Cogong Kabupaten Musi Rawas.

\section{Metode Penelitian}

Penelitian ini bersifat deskriptif kualitatif, dengan menentukan 3 stasiun pengamatan. Setiap stasiun terdiri dari 5 transek dengan luas satu transek pengamatan 100x100 m. Stasiun yang akan di gunakan dalam penelitian ini yaitu: wilayah kaki Bukit Cogong (Stasiun I), wilayah bagian tengah dari Bukit Cogong (Stasiun II), dan wilayah bagian puncak Bukit Cogong (Stasiun III).

Metode deskriptif bertujuan mendeskripsikan sifat atau karakteristik dari suatu peristiwa yang terjadi saat ini (Noor, 2011). Adapun subjek penelitian adalah semua jenis-jenis capung yang ditemukan di Bukit Cogong Kabupaten Musi Rawas yang kemudian diamati berdasarkan ciri-ciri morfologinya dan berdasarkan famili Libelliludae. Penelitian ini dilakukan pada bulan Februari sampai Mei 2019 dengan waktu penelitian dari pagi (08.00 WIB) sampai sore $(17.00$ WIB) dan dilakukan dengan menggunakan teknik purposive sampling yaitu peneliti turun langsung menuju ke lokasi yang akan diteliti (Sugiyono, 2016). Identifikasi capung dilakukan dengan mengamati karakter morfologisnya menggunakan acuan buku Entomologi Serangga (Hadi et al., 2009) dan buku Kunci Determinasi (Siwi, 1991). Peta lokasi Bukit Cogong ditunjukkan pada Gambar 1 dan lokasi penelitian pada Gambar 2. 


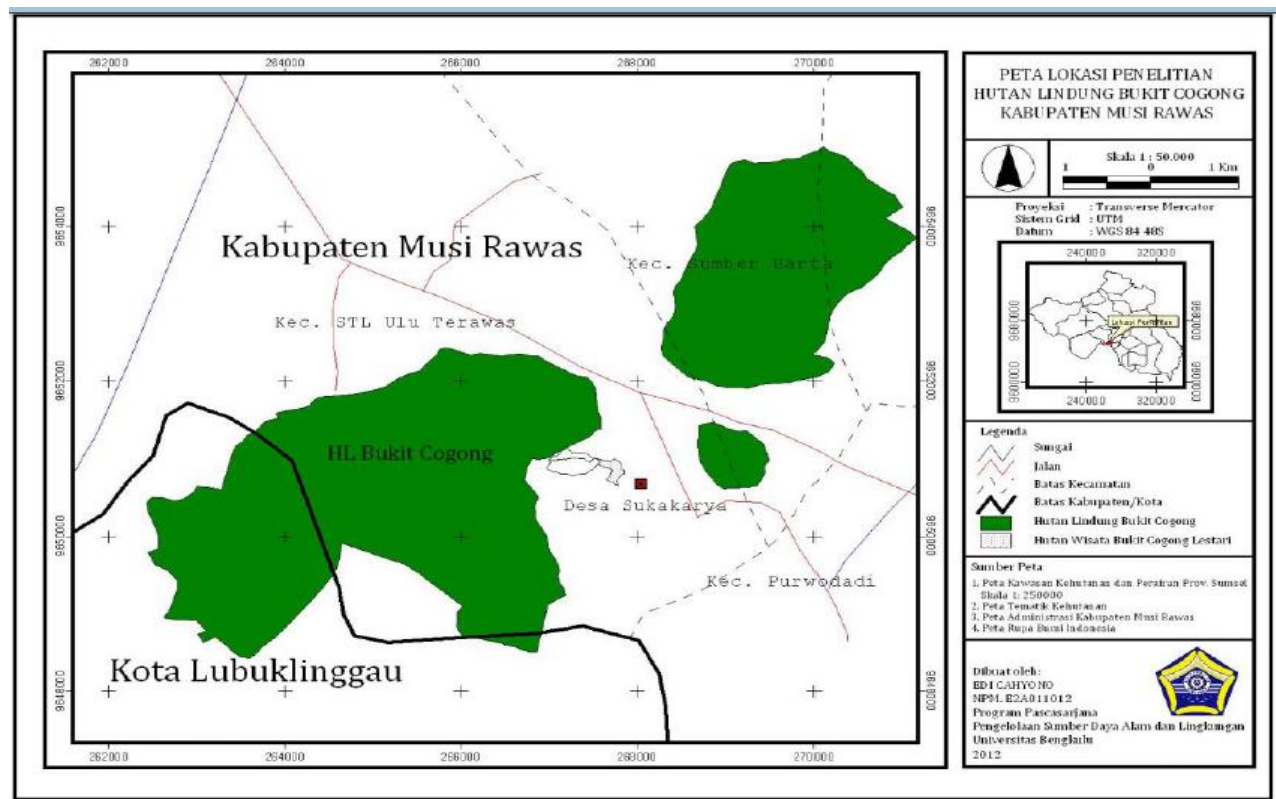

Gambar 1. Peta Bukit Cogong (Sumber: Cahyono, 2013)

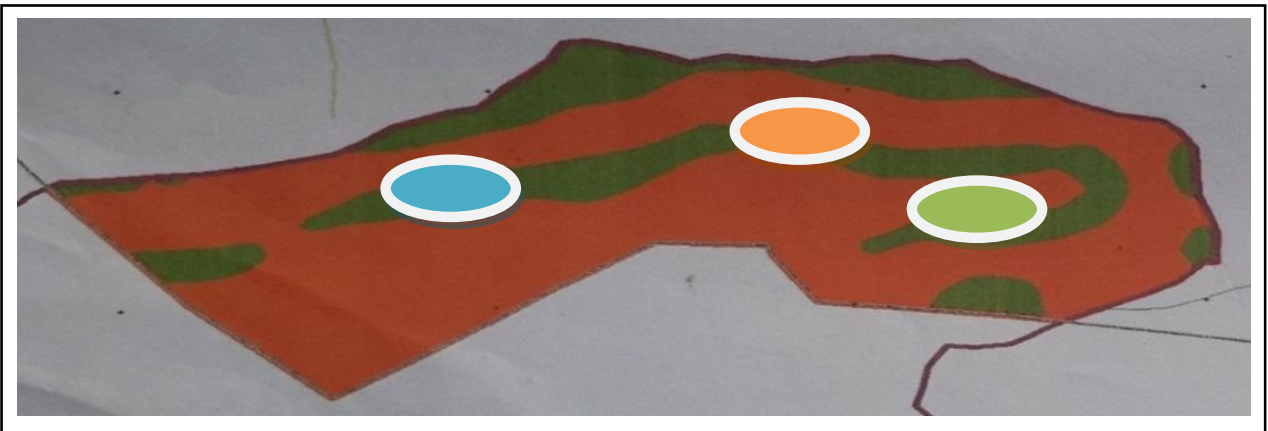

Gambar 2. Lokasi Penelitian (Sumber: Kelompok Tani Hutan, 2015)

Keterangan Gambar 2:

Hutan Perlindungan Bukit Cogong II (Bukit Besar)

Hutan Pemanfaatan

Stasiun I

Stasiun II

Stasiun III

Analisis data meliputi komposisi jenis $(\mathrm{KJ})$, indeks keanekaragaman $\left(\boldsymbol{H}^{\prime}\right)$, indeks keseragaman (E) dan indeks dominansi (Samitra \& Rozi, 2018). Komposisi jenis (KJ) adalah jumlah spesies-i per jumlah seluruh total individu yang tertangkap, dengan rumus berikut :

$$
K J=\frac{n i}{N} \times 100 \%
$$

Keterangan :

$\mathrm{KJ}=$ Komposisi jenis (\%)

$\mathrm{Ni}=$ jumlah individu spesies-i

$\mathrm{N}=$ jumlah total individu semua spesies
Sedikit atau banyaknya keanekaragaman spesies dapat dilihat dari indeks keanekaragaman $\left(H^{\prime}\right)$. Keanekaragaman $\left(H^{\prime}\right)$ mempunyai nilai terbesar jika semua individu berasal dari spesies yang berbeda-beda. Indeks keanekaragaman dapat dihitung dengan menggunakan rumus Shannon-Wienner, yaitu:

$H^{\prime}=-\Sigma \frac{n 1}{N} \times \ln \frac{n \mathbf{1}}{N}$

Keterangan :

$\mathrm{H}^{\prime}$ = indeks keanekeragaman

$\mathrm{n} 1=$ jumlah individu jenis ke- $\mathrm{i}$

$\mathrm{N}$ = Jumlah individu seluruh jenis 
Nilai indeks keanekaragaman ditunjukkan pada Tabel 1.

Nilai indeks keseragaman (E) yang tinggi menunjukkan kelimpahan yang hampir seragam dan merata antar jenis. Nilai indeks keseragaman (E) dapat dihitung menggunakan rumus:

$\mathbf{E}=\frac{H r}{\ln S}$

Keterangan :

$\mathrm{E}=$ indeks kemerataan jenis

$\mathrm{H}^{\prime}=$ indeks keanekeragaman

$\mathrm{S}=$ Jumlah jenis yang ditemukan

Nilai indeks keseragaman ditunjukkan pada Tabel 2.
Jika nilai indeks keseragaman mendekati 0 dapat diartikan dalam ekosistem/komunitas tersebut terjadi kecendrungan dominansi spesies tertentu, dan jika nilai mendekati 1 maka ekosistem/komunitas berada dalam kondisi relatif stabil dan penyebaran spesies merata. Indeks dominansi digunakan untuk mengetahui dominansi spesies pada suatu daerah. Indeks dominansi dihitung dengan menggunakan rumus sebagai berikut:

$C=\Sigma(n i / N)^{2}$

Keterangan :

$\mathrm{C}=$ indeks dominansi

ni $=$ jumlah individu spesies $-\mathrm{i}$

$\mathrm{N}=$ jumlah total individu semua spesies

Nilai indeks dominansi ditunjukkan pada Tabel 3.

Tabel 1. Kriteria Indeks Keanekaragaman

\begin{tabular}{lll}
\hline \hline Indeks Ekologi & Nilai & Kategori \\
\hline \hline & $\boldsymbol{H}^{\prime} \leq 2,0$ & Rendah \\
Indeks Keanekargaman $\left(\boldsymbol{H}^{\prime}\right)$ & $2,0<\boldsymbol{H}^{\prime} \leq 3,0$ & Sedang \\
& $\boldsymbol{H}^{\prime} \geq 3,0$ & Tinggi \\
\hline \hline
\end{tabular}

Tabel 2. Kriteria Indeks Keseragaman

\begin{tabular}{lll}
\hline \hline Indeks Ekologi & Nilai & Kategori \\
\hline \hline & $\mathrm{E}<0,5$ & Keseragaman populasi kecil, komunitas tertekan \\
Indeks Keseragaman $(\mathrm{E})$ & $0,50>\mathrm{E} \leq 0,75$ & Keseragaman populasi sedang, komunitas labil \\
& $0,75<\mathrm{E} \leq 1$ & Keseragaman populasi tinggi, komunitas stabil \\
\hline \hline
\end{tabular}

Tabel 3. Kriteria Indeks Dominansi

\begin{tabular}{lll}
\hline \hline Indeks Ekologi & Nilai & Kategori \\
\hline \hline & $0,00<\mathrm{C} \leq 0,5$ & Rendah \\
Indeks Dominansi $(\mathrm{C})$ & $0,50>\mathrm{C} \leq 0,75$ & Sedang \\
& $0,75<\mathrm{C} \leq 1$ & Tinggi \\
\hline \hline
\end{tabular}

\section{Hasil dan Pembahasan}

Berdasarkan hasil penelitian, didapatkan 5 spesies capung dari famili Libellulidae (Tabel 4), yaitu Orthetrum sabina, Neurothemis fluctuans, Bracythemis contaminata, Rhodothemis rufa, dan Onycothemis culminicola. Jumlah individu yang ditemukan di Bukit Cogong sebanyak 82, dari semua stasiun penelitian. Data ini ditunjukkan pada Tabel 5.

Tabel 4. Spesies capung di Bukit Cogong Kabupaten Musi Rawas

\begin{tabular}{lll}
\hline Kelas & Famili & Spesies \\
\hline \hline Insecta & Libellulidae & Orthetrum sabina \\
& Neurothemis fluctuans \\
& Bracythemis contaminata \\
& Rhodothemis rufa \\
& Onycothemis culminicola \\
\hline \hline
\end{tabular}


Tabel 5. Jumlah individu tiap spesies capung famili Libellulidae yang tertangkap di setiap stasiun penelitian

\begin{tabular}{llccc}
\hline \hline \multirow{2}{*}{ No } & Nama Spesies & \multicolumn{3}{c}{ Stasiun Penelitian } \\
\cline { 3 - 5 } & & Stasiun I & Stasiun II & Stasiun III \\
\hline \hline 1 & Orthetrum sabina & 15 & 17 & 6 \\
2 & Neurothemis fluctuans & 3 & 3 & 3 \\
3 & Bracythemis contaminata & 7 & 9 & 4 \\
4 & Rhodothemis rufa & 6 & 4 & 0 \\
5 & Onycothemis culminicola & 1 & 2 & 2 \\
\hline Jumlah & 32 & 35 & 15 \\
\hline \hline
\end{tabular}

Berdasarkan tabel diatas, diketahui bahwa, jumlah individu yang diperoleh di stasiun I berjumlah 32, stasiun II berjumlah 35, dan stasiun III berjumlah 15. Spesies Orthetrum sabina merupakan spesies yang sering ditemui pada ketiga stasiun tersebut. Orthetrum Sabina memiliki toraks berwarna hijau dengan garis corak berwarna hitam, ekor yang berwarna hitam dengan corak warna putih, abdomennya ramping, kaki berwarna hitam dan sayapnya berwarna hitam dan memiliki corak berwarna kuning. Perutnya berwarna kuning kehijauan, ditandai warna hitam, tanda pucat pada segmen empat abdomen tidak meluas ke bagian posterior bila di lihat dari atas (Sigit et al., 2013).

Sedangkan spesies yang tertangkap hanya di stasiun I dan II adalah Rhodothemis rufa. Capung jenis ini secara keseluruhan berwarna merah kecoklatan. Mata majemuk cokelat gelap dan fronsnya berwarna merah, Sintoraks merah kecokelatan dengan garis merah terang di sisi atas mulai dekat mata majemuk sampai dekat abdomen. Abdomen merah kecokelatan tanpa bintik hitam di sisi atas, dan panjang abdomen 25-29 mm. kedua sayap transparan, di pangkal sayap belakang terdapat bercak cokelat, dan pterostigma berwarna cokelat. Tungkai capung ini hitam, dengan seta (rambut) yang panjang (Sigit et al., 2013).

Komposisi jenis merupakan suatu susunan dan jumlah capung famili Libellulidae yang tertangkap di Bukit Cogong Kabupaten Musi Rawas. Komposisi jenis capung yang tertangkap ditunjukkan pada Tabel 6.

Tabel 6. Nilai komposisi jenis

\begin{tabular}{lll}
\hline \hline No & Spesies & Komposisi Jenis (\%) \\
\hline \hline 1. & Orthetrum sabina & 46,3414634 \\
2. & Neurothemis fluctuans & 10,9756098 \\
3. & Bracythemis contaminata & 24,3902439 \\
4. & Rhodothemis rufa & 12,1951220 \\
5. & Onycothemis culminicola & 6,0975610 \\
\hline \hline
\end{tabular}

Berdasarkan Tabel 6 dapat disimpulkan bahwa komposisi jenis capung famili Libellulidae di Bukit Cogong Kabupaten Musi Rawas yang paling tinggi yaitu spesies Orthetrum sabina dengan komposisi sebesar 46,34 \%. Orthetrum sabina merupakan predator yang ganas dengan mangsa wereng kutu daun, kupu-kupu lebah, bahkan capung lain atau capung jarum. Spesies ini sangat adaptif, dapat hidup di lingkungan air yang kurang bagus dan hidup soliter. Selain itu, capung ini biasanya hinggap di semak dan ranting kering untuk waktu yang lama, hidupnya juga bisa di suhu yang tinggi dan rendah (Sigit et al., 2013). Penelitian ini diperkuat dengan pendapat Patty (2006) yang menyatakan bahwa anggota kelompok ini jumlahnya sangat besar, banyak terdapat di sekitar kolam dan rawa-rawa. Namun ada juga yang terdapat di daerah persawahan diantaranya adalah Ortherum sabina.

Sedangkan yang memiliki komposisi jenis paling rendah adalah Onycothemis culminicola. Jenis capung ini adalah yang paling sedikit ditemukan. Capung ini memiliki mobilitas yang tinggi, sehingga sulit ditangkap. Hal ini sesuai dengan pendapat Kamaludin et al. (2013) yang menyatakan bahwa capung ini berukuran besar, berwarna dominan hijau dan coklat dengan bercak biru pada abdomen. Sering bertengger di bawah kanopi pohon dan bambu. 
Capung ini merupakan penerbang cepat, aktif di pagi dan sore hari. Pendapat serupa juga dikemukakan oleh Sigit et al. (2013), yang menyatakan bahwa spesies ini sangat aktif pada pagi dan siang hari, sedangkan di sore hari jarang di temui, dan sering ditemukan terbang dengan kecepatan tinggi di atas permukaan air, sesekali hinggap di ranting tanaman sekitar perairan. Spesies ini sangat sensitif terhadap kehadiran obyek yang mendekat dan akan segera terbang menghindar. Habitatnya dapat ditemui di sekitar perairan yang bersih dengan vegetasi rumput, semak, rumpun bambu, dan tanaman besar (Sigit et al. , 2013). Kondisi perairan di Bukit Cogong sekarang sudah berkurang karena adanya pembangunan sumber air PAM, kemudian di kawasan Bukit Cogong vegetasi bambu jauh dari perairan sehingga menjadi salah satu faktor berkurangnya spesies ini, sehingga sulit ditemukan.

Indeks keanekaragaman merupakan salah satu dari bagian struktur komunitas capung, dimana indeks keanekaragaman digunakan untuk melihat tingkat keanekaragaman jenis capung famili Libellulidae di bukit Cogong Kabupaten Musi Rawas yang dapat dilihat pada Tabel 7 .

Tabel 7. Nilai Indeks Keanekaragaman

\begin{tabular}{llll}
\hline \hline No. & Stasiun & Nilai Indeks Keanekaragaman $\left(\mathbf{H}^{\prime}\right)$ & Kategori \\
\hline \hline 1. & I & 1,33 & Rendah \\
2. & II & 1,32 & Rendah \\
3. & III & 1,31 & Rendah \\
\hline \hline
\end{tabular}

Analisis indeks keanekaragaman $\left(\mathrm{H}^{\prime}\right)$ pada capung famili Libellulidae di Bukit Cogong Kabupaten Musi Rawas menunjukan kategori rendah, dengan nilai berturut-turut pada stasiuan I, II, dan III yaitu: 1,33, 1,32, dan 1,31. Indeks Keanekaragaman (H') memberikan gambaran seberapa melimpah tingkat keanekaragaman spesies pada masingmasing stasiun. Hal ini menunjukkan bahwa keadaan capung famili Libellulidae yang ditemukan di Bukit Cogong memiliki produktivitas rendah, sehingga keanekaragamannya tidak dalam keadaan seimbang atau mengalami perubahan. Pendapat tersebut didukung oleh Mardiyanti et al. (2013) yang menyatakan bahwa karakteristik komunitas pada suatu lingkungan adalah keanekaragaman. Makin beragam komponen biotik, maka makin tinggi pula tingkat keanekaragaman spesies dan sebaliknya.

Data indeks keseragaman jenis capung famili Libellulidae di Bukit Cogong Kabupaten Musi Rawas dapat dilihat pada Tabel 8.

Tabel 8. Nilai Indeks Keseragaman

\begin{tabular}{llll}
\hline \hline No. & Stasiun & Nilai Indeks Keseragaman $(\mathbf{E})$ & Kategori \\
\hline \hline 1. & I & 0,83 & Tinggi \\
2. & II & 0,82 & Tinggi \\
3. & III & 0,94 & Tinggi \\
\hline \hline
\end{tabular}

Berdasarkan Tabel 8 diketahui bahwa hasil analisis indeks keseragaman pada jenis capung famili libellulidae di Bukit Cogong Kabupaten Musi Rawas menunjukan nilai sebesar 0,83 pada stasiun I kemudian pada stasiun II sebesar 0,82 dan pada stasiun III sebesar 0,94. Data tersebut menunjukkan bahwa ketiga stasiun memiliki kategori keseragaman populasi tinggi dan komunitas yang stabil. Hal ini sesuai dengan pendapat Sagala, et al. (2014) bahwa kriteria nilai keseragaman jenis belalang yaitu nilai $\mathrm{E}$ mendekati 1 maka penyebaran individu antar jenis relatif sama.

Indeks dominansi digunakan untuk memperoleh informasi mengenai jenis capung famili Libellulidae di Bukit Cogong Kabupaten Musi Rawas yang mendominansi pada suatu komunitas yang di temukan. Indeks dominansi jenis capung famili Libellulidae di Bukit Cogong Kabupaten dapat dilihat pada Tabel 9. 
Tabel 9. Nilai Indeks Dominansi

\begin{tabular}{llll}
\hline \hline No. & Stasiun & Nilai Indeks Dominansi $(\mathbf{C})$ & Kategori \\
\hline \hline 1. & I & 0,31 & Rendah \\
2. & II & 0,33 & Rendah \\
3. & III & 0,29 & Rendah \\
\hline \hline
\end{tabular}

Data pada Tabel 9 menunjukkan bahwa nilai indeks dominansi dari ketiga stasiun tersebut memiliki nilai sama-sama rendah. Hal ini sesuai dengan nilai indeks keanekaragaman yang juga termasuk kategori rendah. Menurut Indriyanto (2012), suatu komunitas dikatakan memiliki keanekaragaman spesies yang rendah jika komunitas itu disusun oleh sedikit spesies atau hanya sedikit spesies yang dominan. Hasil penelitian pun menunjukkan hanya ada 1 spesies dominan yang ditemukan pada 3 stasiun. Kondisi ini didukung dari hasil observasi yaitu adanya perubahan lahan alami Bukit Cogong menjadi pemukiman dan tempat rekreasi sehingga mengganggu habitat capung terutama famili Libelulidae.

\section{Simpulan}

Jenis capung dari famili Libellulidae yang ditemukan di Bukit Cogong Kabupaten Musi Rawas ada 5 spesies, yaitu: Orthetrum sabina, Neurothemis fluctuans, Bracythemis contaminata, Rhodothemis rufa, dan Onycothemis culminicola dengan total individu yang tertangkap sebanyak 82. Komposisi jenis tertinggi yaitu Orthetrum sabina sebesar $46,34 \%$, sedangkan yang terendah yaitu Onycothemis culminicola sebesar 6,09\%. Indeks keseragaman pada seluruh stasiun termasuk kategori tinggi, komunitas stabil dan indeks dominansi (C) pada seluruh stasiun termasuk kategori rendah. Indeks keanekaragaman capung famili Libellulidae di Bukit Cogong Kabupaten Musi Rawas termasuk kategori rendah dengan nilai sebesar 1,61 .

\section{Ucapan Terima Kasih}

Penulis mengucapkan terima kasih kepada Direktorat Riset dan Pengabdian Masyarakat (DRPM) Kementrian Riset Teknologi dan Pendidikan Tinggi Indonesia yang telah mendanai penelitian ini melalui pendanaan Penelitian Dosen Pemula (PDP) Tahun 2019.

\section{Daftar Pustaka}

Ansori. (2008). Keanekaragaman Nimfa Odonata (Dragonfiles) di Beberapa Persawahan. Jurnal Exacta. Vol 6. No 2. Hal 42-50.

Cahyono. (2013). Valuasi Ekonomi Hutan Lindung Bukit Cogong. TESIS. Bengkulu. Universitas Bengkulu. Hal 23

Hadi, M., Tarwotjo, U., Rahadian, U. (2009). Biologi Insekta Entomologi. Graha Ilmu. Yogyakarta.

Kamaludin N, Pamungkas D. W., Nugrahaningrum A dan Sigit W. (2016). Mengungkap Potensi Hulu Bengawan Solo. Yogyakarta: Indonesia Dragonfly Society. Hal 42

Kelompok Tani Hutan. (2015). Rencana Umum Hutan Kemasyarakat Hutan Lindung Bukit Cogong. Musi Rawas. Hal 5

Mardiyanti, D. E., Wicaksono, K. P., Baskara, M. (2013). Dinamika Keanekaragaman Spesies Tumbuhan Pasca Pertanian Padi. Jurnal Produksi Tanaman. Vol 1. No 1. Hal 24-35

Noor, (2011). Penelitian Kualitatif. Jakarta: PT Rineka Cipta. Hal 111

Pamungkas, D. W., Ridwan, M. (2015). Keragaman Jenis Capung dan Capung Jarum (Odonata) di beberapa Sumber Air. Pros Sem Nas Masy Biodiv Indon. Vol 1. No 6. Hal 12951301.

Patty, N. (2006). Keanekaragaman Jenis Capung (Odonata) di Situ Gintung Ciputat, Tangerang. Skripsi tidak di terbitkan Jakarta: Fakultas Sains dan Teknologi Universitas Islam Negeri Syarif Hidayatullah. Hal 18

Rizal, S. \& Hadi, M. (2015). Inventarisasi Jenis Capung (Odonata) Pada Areal Persawahan. BIOMA. Vol 17. No 1. Hal 16-20.

Sagala, S., L. Bramawanto, R., Anastasia, R. T. D., Kuswardani, Pranowo, W., S., (2014). Distribusi Logam Berat di Perairan Natuna Distribution of Heavy Metals in Natuna 


\section{Keanekaragaman Jenis Capung}

Coastal Waters. Jurnal Ilmu dan Teknologi Kelautan Tropis, 6(2): 297-310.

Samitra, D. \& Rozi, Z., F. (2018). Keanekaragaman Ikan di Sungai Kelingi Kota Lubuklinggau. Jurnal Biota, 4 (1): 1-6.

Sigit W, Feriwibisono B, Nugrahani M P, Putri B dan Makitan T. (2013). Naga Terbang Wendit. Keanekaragaman Capung Perairan Wendit, Malang Jawa Timur. Jawa Timur: Indonesia Dragonfly society. Hal 58-78
Siwi. (1991). Kunci Determinasi Serangga. Yogyakarta. Kanisius.

Sugiyono. (2016). Penelitian Kuantitatif, Kualitatif dan $R$ dan D. Bandung: Alfabeta. Hal 85

Suriana, adi, d. A., Hardiyanti, D. W. O.. (2014). Inventarisasi Capung (Odonata) di Sekitar Sungai dan Rawa Moramu. Biowallacea. Vol 1. Hal 49-62. 